\title{
Correlations between immunogenicity, drug levels, and disease activity in an Italian cohort of rheumatoid arthritis patients treated with tocilizumab
}

\author{
This article was published in the following Dove Press journal: \\ Biologics:Targets and Therapy \\ II March 2016 \\ Number of times this article has been viewed
}

\section{Maurizio Benucci' \\ Francesca Meacci \\ Valentina Grossi ${ }^{2}$ \\ Maria Infantino ${ }^{2}$ \\ Mariangela Manfredi ${ }^{2}$ \\ Emanuele Bellio ${ }^{2}$ \\ Valerio Bellio ${ }^{2}$ \\ Francesca Li Gobbi' \\ Laura Bazzichi \\ Paolo Moscato 4 \\ Dario Caputo 4 \\ Gianantonio Saviola ${ }^{5}$ \\ Rossella Talotta ${ }^{6}$ \\ Piercarlo Sarzi-Puttini ${ }^{6}$ \\ Fabiola Atzeni ${ }^{7}$ \\ 'Rheumatology Unit, Ospedale San Giovanni di Dio, Florence, Italy; ${ }^{2}$ Allergology and Immunology Laboratory, Ospedale San Giovanni di Dio, Florence, Italy; ${ }^{3}$ Rheumatology Unit, University of Pisa, Pisa, Italy; ${ }^{4}$ Internal Medicine and Rheumatology Unit, University of Salerno, Salerno, Italy; ${ }^{5}$ Rheumatology Unit, Salvatore Maugeri Foundation, Mantua, Italy; ${ }^{6}$ Rheumatology Unit, Ospedale Luigi Sacco, Milan, Italy; ${ }^{7}$ R CCS Galeazzi Orthopedic Institute, Milan, Italy}

Correspondence: Maurizio Benucci Rheumatology Unit, Ospedale San Giovanni di Dio, ASL 10 Florence, Via di Torregalli 3, 50 I 43 Florence, Italy Tel +390556932636 Fax +3905 56932099

Email maurizio.benucci@usicentro. toscana.it

\begin{abstract}
The aim of this study was to evaluate the real-life immunogenicity of anti-drug antibodies, drug levels, and disease activity in an Italian cohort of rheumatoid arthritis patients treated with tocilizumab (TCZ). We evaluated $126 \mathrm{TCZ}$-treated patients with rheumatoid arthritis

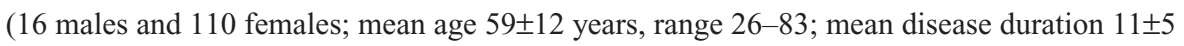
years) with inadequate 12 -week response to any synthetic and biological disease-modifying anti-rheumatic drugs, in a retrospective analysis. One-hundred and seven patients were treated with methotrexate mean dose $12.6 \pm 1.3 \mathrm{mg} /$ week in combination with TCZ, 13 received TCZ monotherapy, and six received leflunomide $20 \mathrm{mg}$ /day plus TCZ; all patients were treated with prednisone mean dose 6.4 $\pm 1.2 \mathrm{mg} /$ day. They had a 28-joint Disease Activity Score (DAS28) of $>3.2$, an erythrocyte sedimentation rate (ESR) of $>30 \mathrm{~mm} / \mathrm{hour}$, and CRP levels of $>1.0 \mathrm{mg} / \mathrm{dL}$. We evaluated at baseline and after 6 months of treatment: DAS28; rheumatoid factor (RF) IgM, IgA, and IgG; anti-citrullinated peptide antibody; ESR; CRP; TNF- $\alpha$; and IL-6. TCZ and antiTCZ antibodies were detected using LISA-TRACKER Duo TCZ. TCZ levels of $<10 \mu \mathrm{g} / \mathrm{mL}$ were considered low and $>10 \mu \mathrm{g} / \mathrm{mL}$ high. After 6 months of treatment only one patient was positive for anti-TCZ antibodies. There were correlations between DAS28, ESR, and CRP and IL-6 levels in all patients. Comparison of the 84 patients with TCZ levels of $<10 \mu \mathrm{g} / \mathrm{mL}$ and the 42 with TCZ levels of $>10 \mu \mathrm{g} / \mathrm{mL}$ showed the following differences: DAS28: $3.09 \pm 1.32 \mathrm{vs} 2.78 \pm 1.32$, $P=0.0005$; ESR: $27 \pm 14.8$ vs $14 \pm 12 \mathrm{~mm} /$ hour, $P=0.0001$; CRP: $1.47 \pm 1.05$ vs $0.65 \pm 0.80 \mathrm{mg} / \mathrm{dL}$, $P=0.0086$; TNF- $\alpha$ : $10.2 \pm 1.2$ vs $9.9 \pm 1.1 \mathrm{pg} / \mathrm{mL}, P=0.999$; IL-6: $3.65 \pm 4.75$ vs $3.62 \pm 4.41 \mathrm{pg} / \mathrm{mL}$, $P=0.97$; anti-citrullinated peptide antibody: $85.2 \pm 93.7$ vs $86.7 \pm 90.3 \mathrm{IU} / \mathrm{mL}, P=0.94$; RF IgM: $72.4 \pm 62.7$ vs $68.3 \pm 61.6 \mathrm{IU} / \mathrm{mL}, P=0.754$; RF IgA: $41.7 \pm 36.4$ vs $47.8 \pm 42.1 \mathrm{U} / \mathrm{mL}, P=0.449$; and RF IgG: $46.4 \pm 46.1$ vs $59.3 \pm 58.2 \mathrm{U} / \mathrm{mL}, P=0.212$. These findings show that the occurrence of anti-drug antibodies against TCZ is very rare and that there are statistically significant correlations between TCZ levels of $>10 \mu \mathrm{g} / \mathrm{mL}$ and ESR, CRP levels, and DAS28.
\end{abstract}

Keywords: tocilizumab, TCZ drug level, antibodies anti-TCZ

\section{Introduction}

IL-6 is a multifunctional, pro-inflammatory cytokine that regulates inflammation, hematopoiesis, and the immune response, and is over-expressed in a number of inflammatory diseases, including rheumatoid arthritis (RA). It plays a central role in the pathogenesis of RA and its multiple functions contribute to both systemic and arthritic disease signs and symptoms, as well as the joint destruction associated with a poor functional status and disability. ${ }^{1,2}$ Increased IL-6 levels correlate with high CRP, SAA, and 
rheumatoid factor (RF) levels, and erythrocyte sedimentation rate (ESR), ${ }^{3,4}$ and are associated with clinical outcomes such as radiographic changes, the number of affected joints, and the duration of morning stiffness. ${ }^{5,6}$ Tocilizumab (TCZ) is a humanized anti-IL-6R monoclonal antibody that competitively inhibits the binding of IL-6 to both mIL-6R and sIL-6R, thus preventing the activation of gp130 and inhibiting pro-inflammatory cascade. ${ }^{7}$ It is efficacious and generally well tolerated in a wide range of patients with RA when given as monotherapy $^{8}$ or in combination with methotrexate (MTX) ${ }^{9}$ and other disease-modifying anti-rheumatic drugs (DMARDs). ${ }^{10}$ Studies showed that during treatment with anti-TNF drugs the antibody production against these drugs is frequent and affects safety and efficacy, ${ }^{11}$ but this is a rare event during TCZ therapy. The production of antibodies against TCZ was tested using the typical two-step approach: a highly specific, highthroughput enzyme-linked immunosorbent assay (ELISA) with a bridging format for screening and confirming TCZ anti-drug antibodies (ADAs) that was theoretically capable of detecting all isotype responses, and secondary assays in order to characterize the neutralizing capacity of the ADAs, their immunoglobulin isotype, and their binding epitope. ${ }^{12,13}$ Following a regulatory request regarding the TCZ development program, immunogenicity testing was introduced during the course of the ACT-RAY study, and the patients were tested for ADAs and neutralizing antibodies using the available baseline, week 24, and week 52 samples. ${ }^{14}$

The aim of this study was to evaluate TCZ ADA immunogenicity, drug levels, and disease activity in a real-life Italian cohort of TCZ-treated RA patients.

\section{Materials and methods}

We evaluated 126 patients (16 males and 110 females with a mean age of $59 \pm 12$ years, range $26-83$; disease duration $11 \pm 5$ years), who were diagnosed as having RA on the basis of the 1987 American College of Rheumatology (ACR) criteria, ${ }^{15}$ and showed inadequate 12-week response to any synthetic (MTX, sulfasalazine, leflunomide) and biological DMARD (infliximab, etanercept, adalimumab). They had a 28-joint Disease Activity Score (DAS28) of $>3.2$, an ESR of $>30 \mathrm{~mm} /$ hour, and CRP levels of $>1.0 \mathrm{mg} / \mathrm{dL}$. One-hundred and seven patients were treated with MTX (mean dose 12.6 $\pm 1.3 \mathrm{mg} /$ week) in combination with TCZ, 13 patients were receiving TCZ monotherapy, and six leflunomide $20 \mathrm{mg} /$ day plus TCZ; all of the patients were treated with prednisone (mean dose $6.4 \pm 1.2 \mathrm{mg} /$ day).

The following parameters were evaluated at baseline and after 6 months: DAS28; RF IgM (N Latex RF; Siemens AG, Munich, Germany), RF IgA and RF IgG (Enzyme Immuno
Assay; Orgentec Diagnostika GmbH, Mainz, Germany); anticitrullinated peptide antibody (ACPA) (Anti-CCP EDIA ${ }^{\text {TM}}$; Euro-Diagnostica, Malmö, Sweden); ESR (mm/hour); CRP (mg/dL); TNF- $\alpha$ (Human TNF-alpha Quantikine Immunoassay; R\&D Systems, Inc., Minneapolis, MN, USA); and IL-6 (Human IL6 Instant Enzyme-linked Immunosorbent Assay; e Bioscience, Bender MedSystems GmbH, Vienna, Austria).

The ethical consent for this study was provided by the local ethics committee of Ospedale San Giovanni di Dio (Florence, Italy). Patient consent was not sought, owing to the retrospective nature of this study, which was carried out using leftover samples, with all analyses performed blindly, and as all patients' records and information remained anonymous.

\section{TCZ and anti-TCZ assay}

All of the serum samples were analyzed for TCZ levels and anti-TCZ antibodies by Lisa Tacker Duo Tocilizumab (Theradiag, Marne La Vallee, France). This ELISA system allows for the simultaneous detection of both drug and anti-drug antibodies, in a micro-well plate format in which half of the plate is coated with TNF- $\alpha$, to measure TCZ concentration, and the other half is coated with TCZ, for ADA detection. Assays were carried out according to the manufacturer's instruction. Optical density of each well was read at 450 $\mathrm{nm}$. A calibration range allows the quantity of TCZ in each sample to be expressed in $\mu \mathrm{g} / \mathrm{mL}$. TCZ levels of $<10 \mu \mathrm{g} /$ $\mathrm{mL}$ were considered low and $>10 \mu \mathrm{g} / \mathrm{mL}$ high. Similarly, a calibration range allows the quantity of anti-TCZ antibodies in each sample to be expressed in $\mathrm{ng} / \mathrm{mL}$.

\section{Statistical analysis}

Analysis of variance (ANOVA) was used in order to establish whether there were significant differences between the mean values of all the considered variables. ANOVA separates the variance of the data into between- and withingroup components, and $F$ represents the ratio of the two estimates. If the $F$-test $P$-value is $<0.05$, there is a statistically significant difference between the mean values of all of the variables at a significance level of $5 \%$, and subsequent multiple range tests indicate which paired variables have significantly different mean values. It was first determined whether there were any significant differences in each variable at T0 (baseline) and T6 (after 6 months of treatment) by gathering data for $\mathrm{TCZ}<10 \mu \mathrm{g} / \mathrm{mL}$ and $>10 \mu \mathrm{g} / \mathrm{mL}$, and for RF-positivity and negativity. The data were analyzed using SAS statistical software, version 9.2 (SAS Institute Inc., Cary, NC, USA). A $P$-value of $<0.05$ was considered significant. 


\section{Results}

After 6 months of treatment only one patient was positive for anti-TCZ antibodies with a value of $84 \mathrm{ng} / \mathrm{mL}$. Among the patients as a whole, there were correlations between DAS28, ESR, and CRP and IL-6 levels (Figure 1). Two patients withdrew before week 24 due to inefficacy and one due to an adverse event (AE) (transaminases increased). Comparison of the 84 patients with TCZ levels of $<10 \mu \mathrm{g} / \mathrm{mL}$ and the 42 with TCZ levels of $>10 \mu \mathrm{g} / \mathrm{mL}$ showed the following differences: DAS28: $3.09 \pm 1.32$ vs $2.78 \pm 1.32, P=0.0005$; ESR: $27 \pm 14.8$ vs $14 \pm 12 \mathrm{~mm} /$ hour, $P=0.0001$; CRP: $1.47 \pm 1.05$ vs $0.65 \pm 0.80 \mathrm{mg} / \mathrm{dL}, P=0.0086$; TNF: $10.2 \pm 1.2$ vs $9.9 \pm 1.1 \mathrm{pg} / \mathrm{mL}, P=0.999$; IL-6: $3.65 \pm 4.75$ vs $3.62 \pm 4.41 \mathrm{pg} / \mathrm{mL}, P=0.97$; ACPA: $85.2 \pm 93.7$ vs $86.7 \pm 90.3 \mathrm{IU} /$ $\mathrm{mL}, P=0.94$; RF IgM: $72.4 \pm 62.7$ vs $68.3 \pm 61.6 \mathrm{IU} / \mathrm{mL}, P=0.754$; RF IgA: $41.7 \pm 36.4$ vs $47.8 \pm 42.1 \mathrm{U} / \mathrm{mL}, P=0.449$; and RF IgG: 46.4 \pm 46.1 vs $59.3 \pm 58.2 \mathrm{U} / \mathrm{mL}, P=0.212$ (Table 1).

Comparison of the 77 ACPA and RF IgM-positive patients and the 49 who were ACPA and RF IgM-negative did not reveal any differences in the clinical or serological parameters: DAS28: $2.82 \pm 1.34$ vs $2.91 \pm 1.21, P=0,694$; ESR: $16.7 \pm 13.6$ vs $18.7 \pm 15.6 \mathrm{~mm} /$ hour, $P=0.483$; CRP $0.91 \pm 0.85$ vs $0.81 \pm 0.91 \mathrm{mg} / \mathrm{dL}, P=0.713$; TNF- $\alpha$ : $10.31 \pm 1.45$ vs $10.1 \pm 1.31 \mathrm{pg} / \mathrm{mL}, P=0.254$; and IL-6: $3.57 \pm 5.40$ vs $3.69 \pm 3$ $\mathrm{pg} / \mathrm{mL}, P=0.888$ (Table 2 ).

\section{Discussion}

The study results show that the occurrence of TCZ ADAs is very rare (only $1 / 126$ patients after 6 months of treatment).
This is in line with the findings of two other studies published this year: the first analyzed 90 samples and found that only three patients had transient ADAs (low titres, not observed 3 months later); ${ }^{16}$ and the second found no case among 22 patients (18 with RA, three with idiopathic juvenile arthritis, and one with adult-onset Still's disease). ${ }^{17}$

One study has assessed the validity of ELISA for detecting anti-TCZ antibodies using complementary bioanalytical assays to test samples from a subgroup of patients with clinical AEs of a potentially immunogenic nature, who were considered highly likely to have ADAs. ${ }^{18}$ The Phase III program for TCZ consisted of five core studies in which adult RA patients received TCZ 4 or $8 \mathrm{mg} / \mathrm{kg}$ intravenously or a control every 4 weeks, with or without concomitant anti-rheumatic therapy. These studies and their open-label, long-term extensions enrolled a total of 4,199 patients, and clinical AEs of a potentially immunogenic nature occurred in 21 patients during TCZ treatment, eight of whom had an anaphylactic reaction. Eleven of the samples from these 21 patients had tested negative for ADAs upon ELISA screening, and only one tested positive in both subsequent assays; all of the others tested negative. ${ }^{18}$

In the ACT-RAY study, the patients were tested for ADAs and neutralizing antibodies using available baseline, week 24, and week 52 samples (or upon withdrawal before week 52). The rate of total and neutralizing ADAs (seroconversion in a neutralizing assay) was similar in the patients receiving TCZ monotherapy or TCZ plus MTX: $1.5 \%-2.2 \%$ and $0.7 \%-1.8 \% .^{14}$

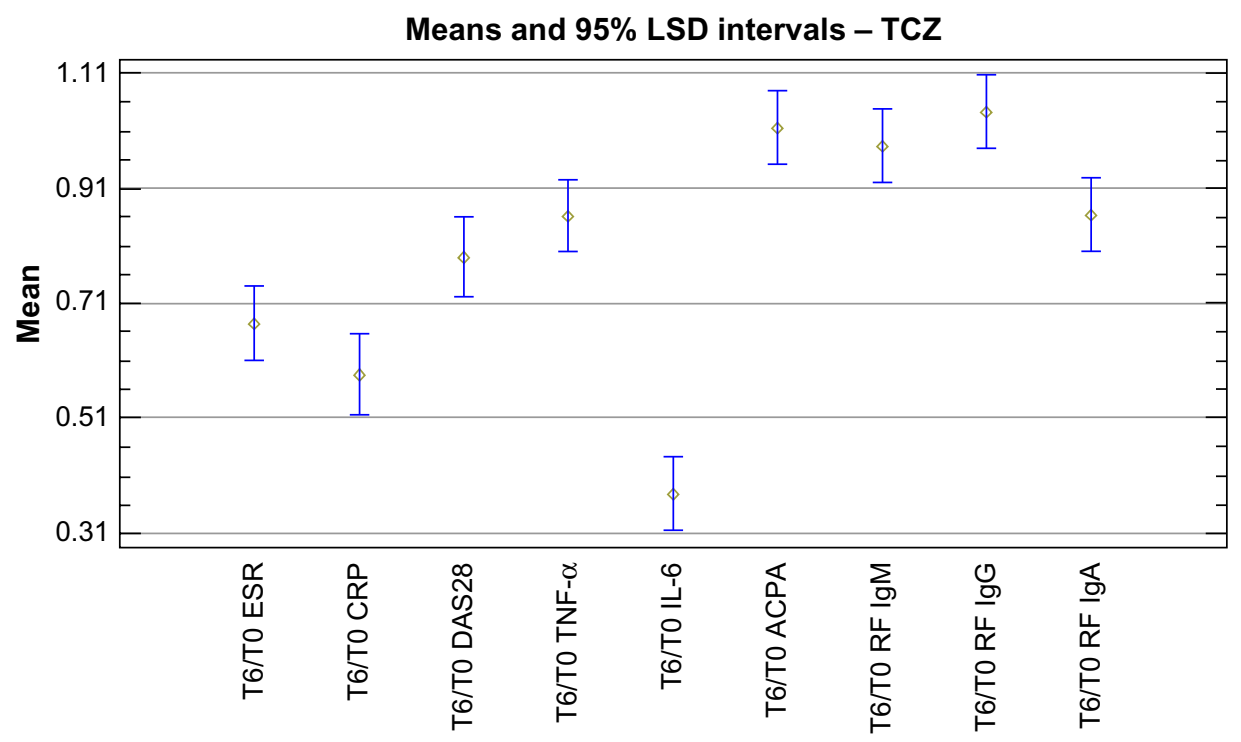

Figure I Correlation between level of TCZ and clinical and laboratory parameters.

Note: T0, baseline; T6, after 6 months of treatment.

Abbreviations: LSD, least significant difference; RF, rheumatoid factor; TCZ, tocilizumab; ESR, erythrocyte sedimentation rate; DAS28, 28-joint Disease Activity Score; ACPA, anti-citrullinated peptide antibody. 
Table I Comparison of the 84 patients with TCZ levels of $<10 \mu \mathrm{g} / \mathrm{mL}$ and the 42 with TCZ levels of $>10 \mu g / \mathrm{mL}$

\begin{tabular}{|c|c|c|c|}
\hline Parameters & Tocilizumab $<10$ ug/mL $(n=84$, mean $\pm S D)$ & Tocilizumab $>10$ ug $/ \mathrm{mL}(\mathrm{n}=42$, mean $\pm S D)$ & $P$-value \\
\hline DAS28 T0 & $4.31 \pm 0.98$ & $4.33 \pm 0.93$ & ns \\
\hline DAS28 T6 & $3.09 \pm 1.32$ & $2.78 \pm 1.32$ & 0.0005 \\
\hline ESR mm/hour T0 & $38 \pm 19$ & $37 \pm 18.2$ & ns \\
\hline ESR mm/hour T6 & $27 \pm 14.8$ & $14 \pm 12$ & 0.0001 \\
\hline CRP mg/dL TO & $3.48 \pm 0.43$ & $3.47 \pm 0.45$ & ns \\
\hline CRP mg/dL T6 & $1.47 \pm 1.05$ & $0.65 \pm 0.80$ & 0.0086 \\
\hline TNF- $\alpha$ pg/mL T0 & $10.2 \pm 1.1$ & $10.3 \pm 0.9$ & ns \\
\hline TNF- $\alpha \mathrm{pg} / \mathrm{mL}$ T6 & $10.2 \pm 1.2$ & $9.9 \pm 1.1$ & 0.999 \\
\hline IL-6 pg/mL T0 & $10.2 \pm 1.2$ & $10.3 \pm 1.3$ & ns \\
\hline IL-6 pg/mL T6 & $3.65 \pm 4.75$ & $3.62 \pm 4.41$ & 0.97 \\
\hline ACPA IU/mL T0 & $91 \pm 98$ & $91 \pm 96$ & ns \\
\hline ACPA IU/mL T6 & $85.2 \pm 93.7$ & $86.7 \pm 90.3$ & 0.94 \\
\hline RF IgM IU/mL T0 & $78 \pm 86$ & $77 \pm 84$ & ns \\
\hline RF IgM IU/mL T6 & $72.4 \pm 62.7$ & $68.3 \pm 61.6$ & 0.754 \\
\hline RF $\lg A \cup / m L$ T0 & $47 \pm 46$ & $48 \pm 46$ & ns \\
\hline $\mathrm{RF} \lg \mathrm{A} U / \mathrm{mL}$ T6 & $41.7 \pm 36.4$ & $47.8 \pm 42.1$ & 0.449 \\
\hline $\mathrm{RF} \lg \mathrm{G} U / \mathrm{mL}$ T0 & $49 \pm 59$ & $48 \pm 58$ & ns \\
\hline RF $\lg G \mathrm{U} / \mathrm{mL}$ T6 & $46.4 \pm 46.1$ & $59.3 \pm 58.2$ & 0.212 \\
\hline
\end{tabular}

Note: T0, baseline; T6, after 6 months of treatment.

Abbreviations: TCZ, tocilizumab; ESR, erythrocyte sedimentation rate; DAS28, 28-joint Disease Activity Score; RF, rheumatoid factor; ACPA, anti-citrullinated peptide antibody; SD, standard deviation; ns, not significant.

The long-term safety and efficacy study of subcutaneous TCZ monotherapy in RA patients found anti-TCZ antibodies in $2.1 \%$ of the patients after 108 weeks. ${ }^{19}$

Finally, the proportion of patients who developed antiTCZ antibodies in the SUMMACTA study of subcutaneous and intravenous TCZ were comparably low (1.6\% and $1.1 \%)$ in both arms, including the switch arms, up to week 97 , and there was no correlation between the development of antiTCZ antibodies and clinical response or AEs. ${ }^{20}$

We observed statistically significant correlations between TCZ levels of $>10 \mu \mathrm{g} / \mathrm{mL}$ and ESR, CRP and DAS28. One study has found that trough serum TCZ levels are lower in patients with high disease activ- ity (DAS28 >5.1) than in those in remission or those with low or moderate disease activity, all of whom had similar levels; none of the other patient parameters were significantly associated or correlated with trough serum TCZ levels. ${ }^{16}$

Another study found heterogeneous serum TCZ levels that did not correlate with disease activity but did correlate with CRP levels; the patients receiving DMARDs with or without glucocorticoids had higher TCZ levels. ${ }^{17}$

We did not find a correlation with IL-6 levels after 6 months when the patients were subdivided on the basis of TCZ levels, but levels decreased in the patients as a whole. The low prevalence of TCZ ADAs may be a consequence

Table 2 Comparison of the 77 ACPA and RF IgM-positive patients and the 49 patients who were ACPA and RF IgM-negative

\begin{tabular}{|c|c|c|c|}
\hline Parameters & ACPA and RF positive patients $(n=77$, mean \pm SD) & ACPA and RF negative patients $(n=49$, mean \pm SD) & $P$-value \\
\hline DAS28 T0 & $4.43 \pm 0.98$ & $4.48 \pm 0.78$ & ns \\
\hline DAS28 T6 & $2.82 \pm 1.34$ & $2.91 \pm 1.21$ & 0.694 \\
\hline ESR mm/hour T0 & $38.10 \pm 18.73$ & $38.18 \pm 19.37$ & ns \\
\hline ESR mm/hour T6 & $16.7 \pm 13.6$ & $18.7 \pm 15.6$ & 0.483 \\
\hline CRP mg/dL TO & $4.15 \pm 6.09$ & $2.57 \pm 2.05$ & ns \\
\hline CRP mg/dL T6 & $0.91 \pm 0.85$ & $0.8 \mathrm{I} \pm 0.91$ & 0.713 \\
\hline TNF- $\alpha \mathrm{pg} / \mathrm{mL}$ T0 & $14 \pm 8.1$ & $12.6 \pm 7.38$ & ns \\
\hline TNF- $\alpha$ pg/mL T6 & $10.3 \mathrm{I} \pm \mathrm{I} .45$ & $|0.1 \pm 1.3|$ & 0.254 \\
\hline IL-6 pg/mL T0 & $12 \pm 7$ & $7.7 \pm 2.9$ & ns \\
\hline IL-6 pg/mL T6 & $3.57 \pm 5.40$ & $3.69 \pm 3$ & 0.888 \\
\hline
\end{tabular}

Note: T0, baseline; T6, after 6 months of treatment.

Abbreviations: ESR, erythrocyte sedimentation rate; DAS28, 28-joint Disease Activity Score; RF, rheumatoid factor; ACPA, anti-citrullinated peptide antibody; SD, standard deviation; ns, not significant. 
of a TCZ-induced IL-6 blockade acting on Tfh CD4 T cells and/or B cells at their different stages of differentiation and maturation. IL-6 is necessary and sufficient for IL-21 production by memory and naïve CD4+ T cells, and recent studies have shown that IL-6 induces antibody production indirectly by acting on $\mathrm{CD} 4+\mathrm{T}$ cells to promote production of high levels of IL-21 which in turn promotes B cell differentiation and increases antibody production. ${ }^{21}$

\section{Conclusion}

Our results confirm that the occurrence of TCZ ADAs is very rare, appearing in only one patient after 6 months of treatment. They also show statistically significant correlations between TCZ levels of $>10 \mu \mathrm{g} / \mathrm{mL}$ and ESR, CRP, and DAS28. However, these findings need to be validated by further studies.

\section{Author contributions}

All authors contributed toward data analysis, drafting and critically revising the paper, gave final approval of the version to be published, and agree to be accountable for all aspects of the work.

\section{Disclosure}

The authors report no conflicts of interest in this work.

\section{References}

1. Gabay C. Interleukin-6 and chronic inflammation. Arthritis Res Ther. 2006; 8 Suppl 2:S3.

2. Lipsky PE. Interleukin-6 and rheumatic diseases. Arthritis Res Ther. 2006; 8 Suppl 2:S4.

3. Houssiau FA, Devogelaer JP, Van Damme J, de Deuxchaisnes CN, Van Snick J. Interleukin-6 in synovial fluid and serum of patients with rheumatoid arthritis and other inflammatory arthritides. Arthritis Rheum. 1988;31(6):784-788.

4. Robak T, Wierzbowska A, Blasinska-Morawiec M, Korycka A, Blonski JZ. Serum levels of IL-6 type cytokines and soluble IL-6 receptors in active B-cell chronic lymphocytic leukemia and in cladribine induced remission. Mediators Inflamm. 1999;8(6):277-286.

5. Madhok R, Crilly A, Watson J, Capell HA. Serum interleukin-6 levels in rheumatoid arthritis: correlations with clinical and laboratory indices of disease activity. Ann Rheum Dis. 1993;52(3):232-234.

6. Straub RH, Muller-Ladner U, Lichtinger T, Scholmerich J, Menninger H, Lang B. Decrease of interleukin 6 during the first 12 months is a prognostic marker for clinical outcome during 36 months treatment with disease-modifying anti-rheumatic drugs. Br J Rheumatol. 1997;36(12): $1298-1303$
7. Choy EH, Isenberg DA, Garrood T, et al. Therapeutic benefit of blocking interleukin-6 activity with an anti-interleukin-6 receptor monoclonal antibody in rheumatoid arthritis: a randomized, doubleblind, placebo-controlled, dose-escalation trial. Arthritis Rheum. 2002;46(12):3143-3150.

8. Jones G, Sebba A, Gu J, et al. Comparison of tocilizumab monotherapy versus methotrexate monotherapy in patients with moderate to severe rheumatoid arthritis: the AMBITION study. Ann Rheum Dis. 2010;69(1):88-96.

9. Smolen JS, Beaulieu A, Rubbert-Roth A, et al. Effect of interleukin-6 receptor inhibition with tocilizumab in patients with rheumatoid arthritis (OPTION study): a double-blind, placebo controlled, randomised trial. Lancet. 2008;371(9617):987-997.

10. Genovese MC, McKay JD, Nasonov EL, et al. Interleukin-6 receptor inhibition with tocilizumab reduces disease activity in rheumatoid arthritis with inadequate response to disease-modifying antirheumatic drugs: the tocilizumab in combination with traditional disease-modifying antirheumatic drug therapy study. Arthritis Rheum. 2008;58(10):2968-2980.

11. Atzeni F, Talotta R, Salaffi F, et al. Immunogenicity and autoimmunity during anti-TNF therapy. Autoimmun Rev. 2013;12(7):703-708.

12. Mire-Sluis AR, Barrett YC, Devanarayan V, et al. Recommendations for the design and optimization of immunoassays used in the detection of host antibodies against biotechnology products. $J$ Immunol Methods. 2004;289(1-2):1-16.

13. Kaliyaperumal A, Jing S. Immunogenicity assessment of therapeutic proteins and peptides. Curr Pharm Biotechnol. 2009;10(4):352-358.

14. Dougados M, Kissel K, Sheeran T, et al. Adding tocilizumab or switching to tocilizumab monotherapy in methotrexate inadequate responders: 24-week symptomatic and structural results of a 2-year randomised controlled strategy trial in rheumatoid arthritis (ACT-RAY). Ann Rheum Dis. 2013;72(1):43-50.

15. Arnett FC, Edworthy SM, Bloch DA, et al. The American Rheumatism Association 1987 revised criteria for the classification of rheumatoid arthritis. Arthritis Rheum. 1988;31(3):315-524.

16. Sigaux J, Hamze M, Daien C, et al. The lack of antidrug antibodies among patients treated with tocilizumab: a clue to good efficacy profiles when used in monotherapy? Ann Rheum Dis. 2015;74(Suppl 2):1050.

17. Rodríguez-Muguruz S, Quirant B, Teniente A, et al. Tocilizumab serum levels and antidrug antibodies and its relationship with disease activity in rheumatic disease. Ann Rheum Dis. 2015;74(Suppl2):731.

18. Stubenrauch K, Wessels U, Birnboeck H, Ramirez F, Jahreis A, Schleypen J. Subset analysis of patients experiencing clinical events of a potentially immunogenic nature in the pivotal clinical trials of tocilizumab for rheumatoid arthritis: Evaluation of an antidrug antibody ELISA using clinical adverse event-driven immunogenicity testing. Clin Ther. 2010;32(9):1597-1609.

19. Ogata A, Amano K, Dobashi H, et al. Longterm Safety and Efficacy of Subcutaneous Tocilizumab Monotherapy: Results from the 2-year Open-label Extension of the MUSASHI Study. J Rheumatol. 2015;42(5):799-809.

20. Burmester GR, Rubbert-Roth A, Cantagrel A, et al. Efficacy and safety of subcutaneous tocilizumab versus intravenous tocilizumab in combination with traditional DMARDs in patients with RA at week 97 (SUMMACTA). Ann Rheum Dis. 2016;75(1):68-74.

21. Yao X, Huang J, Zhong H, et al. Targeting interleukin-6 in inflammatory autoimmune diseases and cancer. Pharmacol Ther. 2014;141(2):125-139. 


\section{Publish your work in this journal}

Biologics: Targets \& Therapy is an international, peer-reviewed journal focusing on the patho-physiological rationale for and clinical application of Biologic agents in the management of autoimmune diseases, cancers or other pathologies where a molecular target can be identified. This journal is indexed on PubMed Central, CAS, EMBase, Scopus

and the Elsevier Bibliographic databases. The manuscript management system is completely online and includes a very quick and fair peerreview system, which is all easy to use. Visit http://www.dovepress. com/testimonials.php to read real quotes from published authors. 